\title{
Influence of Spanish goats on vegetation and soils in Ariz- ona chaparral
}

\author{
KIETH E. SEVERSON AND LEONARD F. DEBANO
}

\begin{abstract}
The key to managing Arizona chaparral depends on creating and maintaining brush-free or savanna-like habitats. Brush control using fire, chemicals, and mechanical methods has been tested previously; but limited information is available on goats. This study evaluated the effect of 4 goat-stocking levels in a short duration grazing system and mechanical brush crushing on chaparral shrubs, herbaceous vegetation, litter, and soils. After 4-1/2 years, percent total shrub cover was lower $(P<0.05)$ on paddocks stocked at $1.4,2.4$, and 4.2 Spanish goats/ha $(35,39$, and $38 \%$, respectively) compared to unstocked controls (51\%). Crushing brush increased the effectiveness of goats; mean total shrub cover was lower $(P<0.05)$ on paddocks where brush was crushed vs not crushed ( 33 and $50 \%$, respectively). Shrubs least preferred by goats were not affected, while preferred browse was impacted at all stocking levels. Goat stocking and brush treatments did not affect perennial herbs, while annuals were generally increased by soil disturbance. Less litter $(P<0.05)$ accumulated under shrubs subjected to heavy stocking levels compared to unbrowsed paddocks. Concentrations of $N$ and $P$ in the soil were also affected $(P<0.05)$ under desert ceanothus (Ceanothus greggii Gray) where the soil bulk density was also increased $(P<0.05)$. While goats can reduce total shrub cover, problems may result. Perennial herbaceous vegetation did not respond. Shrubs preferred by goats were also preferred by native deer. Reduced forage diversity and nutritional stress could result if these species were eliminated from the stand. Also, trampling disturbance by goats affected nitrogen accumulation in the litter and soil, but more importantly heavy browsing may eliminate nitrogen-fixing shrubs.
\end{abstract}

Key Words: Quercus turbinella, litter, soil nitrogen, soil phosphorus, organic carbon, wildlife habitat

Chaparral covers about 1.2 million ha in Arizona. Research has shown that conversion of chaparral to herbaceous vegetation improves water yield, increases forage production, improves wildlife habitat, and provides more aesthetically pleasing landscapes

\footnotetext{
Authors are supervisory range scientist and supervisory soil scientist, USDA Forest Service, Rocky Mountain Forest and Range Experiment Station, Forestry Sciences Laboratory, Arizona State University Campus, Tempe 85287-1304.

The authors extend a sincere thank you to William W. and Edward C. Conway, Greenback Valley Ranch, Tonto Basin, Arizona, and to personnel of the Tonto National Forest, especially David Stewart, for providing the logistical support so necessary for a study of this type. O.D. Knipe's contributions in developing the initial design are gratefully acknowledged. We also extend our appreciation to the host of technicians, led by H. Dwain Smith and Steven Overby, who collected data and analyzed samples.

Manuscript accepted 26 May 1990.
}

that have a reduced fire hazard (Hibbert et al. 1974).

Although considerable research has been conducted on using fire, mechanical methods, and chemicals for controlling brush, only limited research has evaluated biological agents such as goats. Vallentine (1980) quoted a 1970 FAO report that stated goats can be a potent factor in controlling woody plants and in preventing their return in areas of low and erratic precipitation. Davis et al. (1975), using Angora and "milk-type"goats, and Riggs and Urness (1989), using Spanish goats, both reported success in controlling Gambel oak (Quercus gambelii Nutt.). Green et al. (1978) used goats to maintain fuelbreaks in California chaparral. Two shortterm studies in Arizona chaparral are available. Knipe (1983) reported some success in converting chaparral by using Angora goats after prescribed burning and seeding with grasses but indicated success would require intensive management. Boles (1987) stated that shrub live oak (Quercus turbinella Greene), the dominant shrub in his study area, was not being killed by browsing at Angora goat-stocking levels of 6 goats/ha yearlong (average browsing times 7 days with 35 days rest).

We conducted a study designed to determine whether goats in a short duration grazing system can be used to reduce chaparral in Arizona and to evaluate the impact of goat browsing on the vegetation and soil resource. Specific objectives were to determine effects of goat-stocking rates, with and without mechanical brush crushing, on (1) the regrowth and survival of chaparral shrub species, (2) herbaceous vegetation, and (3) litter and soils.

\section{Study Area}

The 435-ha study site was located on the Conway Ranch in Greenback Valley, Ariz., $26 \mathrm{~km}$ SE of Tonto Basin. Elevation ranged from 1,280 to $1,460 \mathrm{~m}$. Soils were derived from diabase and topography was rolling to hilly. Precipitation averaged $508 \mathrm{~mm}$ per year, $60 \%$ falling between October and May and $40 \%$ from June through September.

The site was a shrub live oak-mixed shrub community (Carmichael et al. 1978), the most widespread within the chaparral type. Shrub live oak was the dominant species. Desert ceanothus (Ceanothus greggii Gray) and Pringle manzanita (Arctostaphylos pringlei Parry) occurred in about equal amounts and were the second most abundant. Skunkbush sumac (Rhus trilobata Nutt.) and wait-a-bit (Mimosa biuncifera Benth.) were plentiful. Netleaf hackberry (Celtis reticulata Torr.), Wright silktassel (Garreya wrightii Torr.), and hollyleaf buckthorn (Rhamnus crocea Nutt.) 
occurred with regularity. There were occasional one-seeded juniper (Juniperus monosperma [Engelm] Sarg.) and pinyon (Pinus edulis Engelm.) trees. Herbaceous perennials were occasionally found in openings and under the shrub canopy. These consisted mainly of squirreltail (Sitanion hystrix [Nutt.] J.G. Sm.), blue grama (Bouteloua gracilis [H.B.K.] Steud.), and Palmer penstemon (Penstemon palmeri Gray). Sideoats grama (B. curtipendula [Michx.] Torr.) and curley mesquite (Hilaria belangeri [Steud.] Nash) were common on open, rocky hillsides. Red brome (Bromus rubens $L_{\text {. }}$ ) and Fremont goosefoot (Chenopodium fremontii Wats.) were common annuals.

\section{Methods}

\section{Experimental Design}

Treatments were imposed on a 17-paddock allotment constructed in a "wagon wheel" design. Five of these paddocks were not included in the experimental design but an additional 4 units were fenced separately to serve as unbrowsed control areas, for 16 experimental paddocks on 228 ha. Treatments were 4 stocking levels $(0,1.4,2.4$, and 4.2 goats / ha based on actual days of use in a 1 -year period) and 2 land treatments (brush crushed and not crushed), with each combination replicated 2 times. Stocking levels for moderate ( 2.4 goats/ha) were based on a previous study in Arizona chaparral (Knipe 1983). Light and heavy levels were fixed at approximately one-half and 2 times the moderate rate. Brush was treated with a Marden brush crusher in March-April, 1984. The area was stocked with 600 Spanish goats which were managed as 1 herd, and stocking rate was regulated by paddock size; that is, all paddocks were browsed by the same number of goats. Goats were placed in paddocks on 28 February 1984. Paddocks were browsed in time-controlled moves. Duration of use of each paddock was based on growth state of the plants in the most heavily used paddocks (4.2 goat/ha). In order to keep stocking rates constant and consistent, paddocks stocked at the other levels were used for the same length of time through a full rotation. The general program was to graze each paddock 3 days when plants were growing and 5 days during dormant seasons.

\section{Sampling Methods \\ Vegetation}

Tree, shrub, and half-shrub cover was determined, by species, using the line intercept method (Canfield 1942). The line started at the hub and ran the length of the paddock. Density of herbaceous plants, grasses, and forbs was estimated from $30 \times 61 \mathrm{~cm}$ quadrats placed at regular intervals along the line. The interval was determined by paddock length and a required minimum sample of 100 quadrats per paddock. The number of individuals of each species were counted and converted to density per square meter.

Shrub data were collected in November 1983 (pretreatment), May and October beginning in 1985 through 1987, and in May 1988. Herbaceous data were collected in May and October, 1986 and 1987, and May 1988.

In October 1987, every individual shrub intercepted by the line described above was classified as dead or alive and all live plants were examined for use by goats and assigned to 1 of 4 utilization

Table 1. Percent cover of shrubs over a 4-1/2 year period on paddocks subjected to 4 goat stocking rates and 2 brush treatments, central Arizona. Data expressed as mean \pm standard error.

\begin{tabular}{|c|c|c|c|c|c|c|c|c|c|}
\hline \multirow{3}{*}{\multicolumn{2}{|c|}{ Categories/Time }} & \multicolumn{8}{|c|}{ Stocking rates (goats/ha) } \\
\hline & & \multicolumn{4}{|c|}{ Brush not crushed } & \multicolumn{4}{|c|}{ Brush crushed } \\
\hline & & 0 & 1.4 & 2.4 & 4.2 & 0 & 1.4 & 2.4 & 4.2 \\
\hline $\begin{array}{l}\text { Total } \\
\text { shrub } \\
\text { cover }\end{array}$ & $\begin{array}{r}11 / 83 \\
5 / 85 \\
10 / 85 \\
5 / 86 \\
10 / 86 \\
5 / 87 \\
10 / 87 \\
5 / 88\end{array}$ & $\begin{array}{l}51 \pm 1 a^{*} \\
56 \pm 2 \\
54 \pm 2 \\
58 \pm 1 \\
63 \pm 2 \\
62 \pm 5 \\
63 \pm 6 \\
56 \pm 7 a\end{array}$ & $\begin{array}{l}56 \pm 3 a \\
49 \pm 5 \\
43 \pm 4 \\
54 \pm 5 \\
51 \pm 2 \\
49 \pm 6 \\
43 \pm 4 \\
48 \pm 1 a b\end{array}$ & $\begin{array}{l}64 \pm 3 a \\
53 \pm 1 \\
46 \pm 2 \\
55 \pm 1 \\
51 \pm 1 \\
52 \pm 1 \\
46 \pm 2 \\
47 \pm 1 \mathrm{ab}\end{array}$ & $\begin{array}{l}61 \pm 1 \mathrm{a} \\
42 \pm 5 \\
37 \pm 6 \\
42 \pm 3 \\
48 \pm 7 \\
45 \pm 5 \\
42 \pm 3 \\
41 \pm 4 \mathrm{bc}\end{array}$ & $\begin{array}{l}61 \pm 4 a \\
32 \pm 1 \\
40 \pm 5 \\
44 \pm 1 \\
51 \pm 5 \\
46 \pm 5 \\
47 \pm 4 \\
50 \pm 1 \mathrm{ab}\end{array}$ & $\begin{array}{l}54 \pm 3 \mathrm{a} \\
28 \pm 1 \\
27 \pm 3 \\
31 \pm 4 \\
36 \pm 3 \\
36 \pm 2 \\
31 \pm 1 \\
30 \pm 3 \mathrm{~cd}\end{array}$ & $\begin{array}{l}61 \pm 6 a \\
24 \pm 4 \\
24 \pm 2 \\
32 \pm 1 \\
33 \pm 3 \\
33 \pm 3 \\
30 \pm 7 \\
28 \pm 1 d\end{array}$ & $\begin{array}{l}55 \pm 2 a \\
28 \pm 4 \\
20 \pm 5 \\
27 \pm 6 \\
31 \pm 5 \\
29 \pm 4 \\
27 \pm 6 \\
28 \pm 11 d\end{array}$ \\
\hline $\begin{array}{l}\text { Shrub } \\
\text { live } \\
\text { oak } \\
\text { cover }\end{array}$ & $\begin{array}{r}11 / 83 \\
5 / 85 \\
10 / 85 \\
5 / 86 \\
10 / 86 \\
5 / 87 \\
10 / 87 \\
5 / 88\end{array}$ & $\begin{array}{l}32 \pm 1 a \\
34 \pm 1 \\
34 \pm 1 \\
36 \pm 2 \\
34 \pm 1 \\
36 \pm 1 \\
36 \pm 1 \\
28 \pm 4 a b c\end{array}$ & $\begin{array}{l}27 \pm 8 \mathrm{a} \\
29 \pm 4 \\
24 \pm 6 \\
27 \pm 4 \\
27 \pm 2 \\
26 \pm 5 \\
28 \pm 7 \\
32 \pm 8 \mathrm{abc}\end{array}$ & $\begin{array}{l}34 \pm 1 \mathrm{a} \\
27 \pm 2 \\
23 \pm 1 \\
28 \pm 2 \\
23 \pm 2 \\
25 \pm 3 \\
22 \pm 1 \\
21 \pm 3 \mathrm{bcd}\end{array}$ & $\begin{array}{l}28 \pm 4 a \\
21 \pm 3 \\
18 \pm 1 \\
22 \pm 1 \\
18 \pm 2 \\
20 \pm 1 \\
17 \pm 2 \\
17 \pm 6 \mathrm{~cd}\end{array}$ & $\begin{array}{l}29 \pm 4 a \\
18 \pm 2 \\
24 \pm 6 \\
24 \pm 1 \\
33 \pm 3 \\
31 \pm 2 \\
31 \pm 3 \\
34 \pm 5 a\end{array}$ & $\begin{array}{l}28 \pm 1 \mathrm{a} \\
17 \pm 2 \\
13 \pm 1 \\
17 \pm 2 \\
17 \pm 1 \\
18 \pm 3 \\
19 \pm 3 \\
18 \pm 2 \mathrm{~cd}\end{array}$ & $\begin{array}{l}33 \pm 6 \mathrm{a} \\
11 \pm 2 \\
14 \pm 1 \\
18 \pm 1 \\
16 \pm 1 \\
17 \pm 2 \\
17 \pm 3 \\
15 \pm 3 d\end{array}$ & $\begin{array}{l}30 \pm 2 \mathrm{a} \\
13 \pm 1 \\
12 \pm 2 \\
17 \pm 4 \\
17 \pm 3 \\
17 \pm 3 \\
15 \pm 4 \\
15 \pm 5 d\end{array}$ \\
\hline $\begin{array}{l}\text { Most } \\
\text { preferred } \\
\text { shrubs }\end{array}$ & $\begin{array}{r}11 / 83 \\
5 / 85 \\
10 / 85 \\
5 / 86 \\
10 / 86 \\
5 / 87 \\
10 / 87 \\
5 / 88\end{array}$ & $\begin{array}{l}12 \pm 4 a \\
12 \pm 3 \\
12 \pm 3 \\
12 \pm 2 \\
16 \pm 3 \\
14 \pm 1 \\
16 \pm 3 \\
13 \pm 2\end{array}$ & $\begin{array}{c}13 \pm 2 \mathrm{a} \\
6 \pm 0 \\
8 \pm 2 \\
7 \pm 2 \\
6 \pm 1 \\
6 \pm 1 \\
5 \pm 1 \\
4 \pm 0\end{array}$ & $\begin{array}{l}8 \pm 1 \mathrm{ab} \\
4 \pm 1 \\
3 \pm 0 \\
3 \pm 0 \\
3 \pm 0 \\
3 \pm 0 \\
2 \pm 0 \\
2 \pm 0\end{array}$ & $\begin{array}{l}8 \pm 1 \mathrm{ab} \\
4 \pm 0 \\
2 \pm 0 \\
2 \pm 0 \\
2 \pm 0 \\
3 \pm 0 \\
2 \pm 1 \\
1 \pm 0\end{array}$ & $\begin{array}{l}6 \pm 2 \mathrm{ab} \\
3 \pm 1 \\
3 \pm 1 \\
3 \pm 1 \\
5 \pm 1 \\
5 \pm 0 \\
4 \pm 0 \\
3 \pm 1\end{array}$ & $\begin{array}{c}11 \pm 4 a \\
2 \pm 0 \\
2 \pm 1 \\
2 \pm 1 \\
2 \pm 1 \\
2 \pm 2 \\
2 \pm 2 \\
2 \pm 2\end{array}$ & $\begin{array}{l}5 \pm 2 b \\
1 \pm 1 \\
1 \pm 0 \\
0 \pm 0 \\
1 \pm 0 \\
0 \pm 0 \\
0 \pm 0 \\
0 \pm 0\end{array}$ & $\begin{array}{c}13 \pm 3 a \\
1 \pm 0 \\
1 \pm 1 \\
1 \pm 1 \\
1 \pm 1 \\
0 \pm 0 \\
0 \pm 0 \\
0 \pm 0\end{array}$ \\
\hline $\begin{array}{l}\text { Least } \\
\text { preferred } \\
\text { shrubs }\end{array}$ & $\begin{array}{r}11 / 83 \\
5 / 85 \\
10 / 85 \\
5 / 86 \\
10 / 86 \\
5 / 87 \\
10 / 87 \\
5 / 88\end{array}$ & $\begin{array}{l}9 \pm 1 \mathrm{a} \\
9 \pm 1 \\
8 \pm 0 \\
8 \pm 0 \\
8 \pm 0 \\
8 \pm 1 \\
7 \pm 1 \\
9 \pm 0\end{array}$ & $\begin{array}{l}6 \pm 1 a \\
5 \pm 1 \\
5 \pm 1 \\
5 \pm 1 \\
6 \pm 0 \\
6 \pm 0 \\
7 \pm 2 \\
6 \pm 2\end{array}$ & $\begin{array}{l}16 \pm 3 b \\
16 \pm 2 \\
14 \pm 1 \\
16 \pm 3 \\
16 \pm 0 \\
18 \pm 1 \\
16 \pm 3 \\
16 \pm 1\end{array}$ & $\begin{array}{c}10 \pm 1 \mathrm{a} \\
7 \pm 1 \\
6 \pm 1 \\
7 \pm 2 \\
7 \pm 2 \\
9 \pm 1 \\
7 \pm 1 \\
4 \pm 0\end{array}$ & $\begin{array}{l}9 \pm 9 a \\
3 \pm 3 \\
3 \pm 3 \\
5 \pm 2 \\
4 \pm 2 \\
3 \pm 3 \\
4 \pm 3 \\
4 \pm 3\end{array}$ & $\begin{array}{l}9 \pm 1 \mathrm{a} \\
5 \pm 3 \\
7 \pm 3 \\
7 \pm 3 \\
7 \pm 3 \\
7 \pm 2 \\
7 \pm 2 \\
6 \pm 3\end{array}$ & $\begin{array}{c}16 \pm 4 b \\
4 \pm 1 \\
5 \pm 1 \\
6 \pm 2 \\
6 \pm 2 \\
7 \pm 3 \\
6 \pm 3 \\
6 \pm 2\end{array}$ & $\begin{array}{l}9 \pm 0 \mathrm{a} \\
3 \pm 2 \\
3 \pm 2 \\
5 \pm 3 \\
7 \pm 3 \\
7 \pm 3 \\
7 \pm 4 \\
5 \pm 5\end{array}$ \\
\hline
\end{tabular}

*Values within a row followed by the same letter are not significantly different at the 0.05 probability level. 
classes: 0 = no use, 1 = light use, 2 = intermediate use, and $3=$ heavy use. Classes were summed for each species within each treatment and divided by the total number of shrubs involved for an average utilization index.

\section{Soils and Litter}

The effect of goat browsing on soils was evaluated on paddocks receiving 1 of 3 stocking levels $(0,1.4$, and 4.2 goats / ha yearlong) in July 1988. This sampling design permitted evaluating the effect of both goat browsing and crushing on 6 paddocks. The 6 paddocks were sampled at 3 random locations. At each sampling location, samples of soil and litter were collected from beneath each of 3 shrub species-Pringle manzanita, desert ceanothus, and shrub live oak-and on bare interspace areas between shrubs. On each sampling location, litter and humus samples were collected from within a $0.1-\mathrm{m}^{2}$ sampling frame. The 3 cores were collected to a depth of $3.8 \mathrm{~cm}$ within the sampling frame at each location. After bulk density had been determined on individual cores, the 3 cores collected at each location were composited for subsequent physical and chemical analyses. An additional $500 \mathrm{~g}$ of soil was collected from the 3.9- to 7.6-cm soil depth.

Litter and humus samples were oven-dried, weighed, and ground in a Wiley mill before being analyzed for total nitrogen $(N)$ by the Kjeldahl procedure and total phosphorus (P) following a perchloric acid digestion (Black 1958). Soil samples were ovendried and weighed to determine bulk density. The dried soil samples were further analyzed for organic carbon (OC) (WalkleyBlack), total N (Kjeldahl), total $P$, total potassium (K), and soil texture (hydrometer). Techniques for determining soil chemical properties are described by Page et al. (1982) and physical properties by Klute (1986).

\section{Statistical Analyses \\ Vegetation}

Shrubs were divided into 4 categories for analyses. Total shrubs and shrub live oak, the only species abundant enough to be tested by itself, were the 2 primary categories. The other categories were based on relative palatability to goats (from utilization measure- ments): least preferred included Pringle manzanita, broom snakeweed (Gutierrezia sarothrae [Pursh.] Britt. and Rusby), and sotol (Dasylirion wheeleri Wats.); and the most preferred group included hollyleaf buckthorn, Wrights silktassel, desert ceanothus, menodora (Menodora scabra Gray), and birchleaf mountainmahogany (Cercocarpus betuloides Nutt.).

Pretreatment shrub data were analyzed with one-way analysis of variance (ANOVA) to test the hypothesis that brush cover was similar among paddocks. If the hypothesis was not rejected, analysis proceeded with two-factor (stocking levels and brush treatments) multivariate analysis of variance (MANOVA), repeated measures design, with time as the repeated measure to test the hypothesis that trends over time did not change with either brush treatment or goat-stocking level. The 7 time periods evaluated did not include pretreatment (11/83) data. Orthogonal polynomial contrasts were used to determine trends and compare responses. Cover for total shrubs and for shrub live oak was tested in this manner. For these groups, an ancillary analysis was done for the last time period (May 1988) by using one-way ANOVA again to test the hypothesis that cover was similar among paddocks to provide a supplemental comparison with the pretreatment test.

The most and least preferred categories had pretreatment differences in cover among paddocks and significant brush treatment $X$ grazing level interactions, which preclude use of repeated measures. Hence, pretreatment (November 1983) and the May 1988 treatment sets were tested to insure regressions among treatments were homogeneous. They were then analyzed via analysis of covariance to test the hypothesis that there were no differences in cover of these shrub categories on the last sampling date, adjusted for pretreatment conditions, because of brush treatment and/or goatstocking level. Orthogonal contrasts were used to compare responses.

Herbaceous plant data were combined into 4 categories: perennial and annual grasses, and perennial and annual forbs. No pretreatment data were collected for these groups. Each group was subjected to the same repeated measures test previously described, but significant interactions indicated an invalid procedure. Therefore, each of the 5 sampling times for each of the $\mathbf{4}$ categories was

Table 2. Density (stems $/ \mathrm{m}^{2}$ ) of herbaceous plants over a 2-1/2 year period on paddocks subjected to 4 goat stocking levels and 2 brush treatments, central Arizona. Data expressed as mean \pm standard error.

\begin{tabular}{|c|c|c|c|c|c|c|c|c|c|}
\hline \multirow{3}{*}{\multicolumn{2}{|c|}{ Categories/Time }} & \multicolumn{8}{|c|}{ Stocking rates (goats/ha) } \\
\hline & & \multicolumn{4}{|c|}{ Brush not crushed } & \multicolumn{4}{|c|}{ Brush crushed } \\
\hline & & 0 & 1.4 & 2.4 & 4.2 & 0 & 1.4 & 2.4 & 4.2 \\
\hline $\begin{array}{l}\text { Perennial } \\
\text { grasses }\end{array}$ & $\begin{array}{r}5 / 86 \\
10 / 86 \\
5 / 87 \\
10 / 87 \\
5 / 88\end{array}$ & $\begin{array}{l}1.9 \pm 1.0 \mathrm{ab}^{* *} \\
2.2 \pm 0.9 \mathrm{~b} \\
1.7 \pm 1.6 \\
1.5 \pm 0.4 \\
2.0 \pm 1.1\end{array}$ & $\begin{array}{l}4.7 \pm 1.4 \mathrm{a} \\
10.7 \pm 2.0 \mathrm{a} \\
4.1 \pm 1.3 \\
4.5 \pm 2.4 \\
2.1 \pm 0.8\end{array}$ & $\begin{array}{l}0.3 \pm 0.1 b \\
0.2 \pm 0.1 b \\
1.1 \pm 0.3 \\
0.3 \pm 0.1 \\
0.3 \pm 0.2\end{array}$ & $\begin{array}{l}1.9 \pm 0.5 \mathrm{ab} \\
1.9 \pm 0.5 \mathrm{~b} \\
2.5 \pm 1.0 \\
0.9 \pm 0.2 \\
1.1 \pm 0.4\end{array}$ & $\begin{array}{l}0.4 \pm 0.1 b \\
3.1 \pm 1.0 b \\
0.8 \pm 0.4 \\
0.5 \pm 0.3 \\
0.8 \pm 0.4\end{array}$ & $\begin{array}{l}5.1 \pm 1.1 \mathrm{a} \\
2.4 \pm 0.5 \mathrm{~b} \\
1.2 \pm 0.4 \\
2.6 \pm 1.3 \\
2.3 \pm 1.0\end{array}$ & $\begin{array}{l}0.6 \pm 0.1 b \\
0.5 \pm 0.2 b \\
1.5 \pm 0.4 \\
0.9 \pm 0.3 \\
0.5 \pm 0.2\end{array}$ & $\begin{array}{l}1.8 \pm 0.2 \mathrm{ab} \\
0.3 \pm 0.1 \mathrm{~b} \\
2.1 \pm 0.2 \\
1.0 \pm 0.4 \\
0.7 \pm 04\end{array}$ \\
\hline $\begin{array}{l}\text { Annual } \\
\text { grasses }\end{array}$ & $\begin{array}{r}5 / 86 \\
10 / 86 \\
5 / 87 \\
10 / 87 \\
5 / 88\end{array}$ & $\begin{array}{l}0.9 \pm 0.2 \mathrm{c} \\
3.0 \pm 1.9 \mathrm{c} \\
2.8 \pm 1.8 \mathrm{~b} \\
3.9 \pm 1.8 \mathrm{~b} \\
6.7 \pm 1.4 \mathrm{c}\end{array}$ & $\begin{array}{c}7.4 \pm 0.9 \mathrm{bc} \\
13.4 \pm 2.3 \mathrm{bc} \\
5.7 \pm 2.7 \mathrm{ab} \\
3.7 \pm 1.2 \mathrm{~b} \\
9.3 \pm 2.2 \mathrm{de}\end{array}$ & $\begin{array}{c}11.4 \pm 1.3 \mathrm{bc} \\
4.8 \pm 2.5 \mathrm{bc} \\
6.2 \pm 0.2 \mathrm{ab} \\
4.7 \pm 1.3 \mathrm{~b} \\
34.8 \pm 3.3 \mathrm{bc}\end{array}$ & $\begin{array}{l}40.5 \pm 13.2 \mathrm{ab} \\
33.5 \pm 9.4 \mathrm{ab} \\
10.2 \pm 2.9 \mathrm{ab} \\
14.5 \pm 3.9 \mathrm{ab} \\
41.6 \pm 2.0 \mathrm{ab}\end{array}$ & $\begin{array}{l}52.8 \pm 6.1 \mathrm{a} \\
33.8 \pm 7.5 \mathrm{ab} \\
8.4 \pm 4.6 \mathrm{ab} \\
42.4 \pm 9.7 \mathrm{a} \\
39.1 \pm 1.4 \mathrm{abc}\end{array}$ & $\begin{array}{r}38.0 \pm 6.1 \mathrm{ab} \\
16.6 \pm 3.6 \mathrm{bc} \\
8.5 \pm 2.4 \mathrm{ab} \\
24.5 \pm 3.4 \mathrm{ab} \\
24.5 \pm 4.9 \mathrm{~cd}\end{array}$ & $\begin{array}{l}47.9 \pm 5.8 \mathrm{a} \\
26.7 \pm 6.4 \mathrm{~b} \\
13.4 \pm 2.1 \mathrm{ab} \\
31.2 \pm 14.5 \mathrm{ab} \\
38.5 \pm 0.8 \mathrm{abc}\end{array}$ & $\begin{array}{l}65.4 \pm 12.1 \mathrm{a} \\
57.9 \pm 8.7 \mathrm{a} \\
15.5 \pm 2.0 \mathrm{a} \\
23.5 \pm 2.1 \mathrm{ab} \\
52.4 \pm 6.1 \mathrm{a}\end{array}$ \\
\hline $\begin{array}{l}\text { Perennial } \\
\text { forbs }\end{array}$ & $\begin{array}{r}5 / 86 \\
10 / 86 \\
5 / 87 \\
10 / 87 \\
5 / 88\end{array}$ & $\begin{array}{l}0.5 \pm 0.2 b \\
0.4 \pm 0.1 b \\
3.5 \pm 1.9 \\
0.9 \pm 0.8 \\
3.7 \pm 1.6\end{array}$ & $\begin{array}{l}0.3 \pm 0.0 \mathrm{~b} \\
1.8 \pm 0.1 \mathrm{ab} \\
1.3 \pm 0.7 \\
1.2 \pm 1.3 \\
1.5 \pm 1.4\end{array}$ & $\begin{array}{l}0.6 \pm 0.2 \mathrm{ab} \\
0.9 \pm 0.1 \mathrm{~b} \\
3.3 \pm 0.7 \\
1.9 \pm 1.2 \\
1.3 \pm 0.2\end{array}$ & $\begin{array}{l}0.8 \pm 0.3 \mathrm{ab} \\
3.6 \pm 0.7 \mathrm{a} \\
3.3 \pm 1.1 \\
2.2 \pm 1.5 \\
3.4 \pm 0.2\end{array}$ & $\begin{array}{l}0.8 \pm 0.1 \mathrm{ab} \\
1.6 \pm 0.5 \mathrm{ab} \\
3.4 \pm 0.6 \\
2.3 \pm 1.6 \\
2.7 \pm 1.4\end{array}$ & $\begin{array}{l}1.0 \pm 0.3 \mathrm{ab} \\
1.4 \pm 0.4 \mathrm{~b} \\
2.1 \pm 0.6 \\
2.7 \pm 2.2 \\
2.7 \pm 1.1\end{array}$ & $\begin{array}{l}0.6 \pm 0.1 \mathrm{ab} \\
1.9 \pm 0.1 \mathrm{ab} \\
3.6 \pm 1.5 \\
2.7 \pm 1.0 \\
3.8 \pm 1.3\end{array}$ & $\begin{array}{l}1.8 \pm 0.5 \mathrm{a} \\
1.9 \pm 0.8 \mathrm{ab} \\
3.3 \pm 1.4 \\
1.8 \pm 1.0 \\
2.5 \pm 0.9\end{array}$ \\
\hline $\begin{array}{l}\text { Annual } \\
\text { forbs }\end{array}$ & $\begin{array}{r}5 / 86 \\
10 / 86 \\
5 / 87 \\
10 / 87 \\
5 / 88\end{array}$ & $\begin{array}{l}0.6 \pm 0.1 \mathrm{ab} \\
2.3 \pm 0.6 \mathrm{~b} \\
0.7 \pm 0.6 \\
0.7 \pm 0.6 \\
4.0 \pm 1.2 \mathrm{~b}\end{array}$ & $\begin{array}{l}0.2 \pm 0.1 \mathrm{~b} \\
2.9 \pm 0.3 \mathrm{~b} \\
3.9 \pm 2.8 \\
0.4 \pm 0.2 \\
6.6 \pm 1.0 \mathrm{ab}\end{array}$ & $\begin{array}{l}0.5 \pm 0.1 \mathrm{ab} \\
1.1 \pm 0.4 \mathrm{~b} \\
3.5 \pm 0.5 \\
0.9 \pm 0.2 \\
4.6 \pm 1.4 \mathrm{ab}\end{array}$ & $\begin{array}{c}2.3 \pm 0.3 \mathrm{a} \\
0.6 \pm 0.2 \mathrm{~b} \\
4.2 \pm 1.2 \\
0.3 \pm 0.2 \\
11.6 \pm 0.1 \mathrm{ab}\end{array}$ & $\begin{array}{l}3.0 \pm 1.1 \mathrm{a} \\
0.4 \pm 0.1 \mathrm{~b} \\
2.1 \pm 1.9 \\
0.2 \pm 0.1 \\
6.7 \pm 0.7 \mathrm{ab}\end{array}$ & $\begin{array}{c}0.5 \pm 0.2 \mathrm{ab} \\
1.7 \pm 0.4 \mathrm{~b} \\
4.3 \pm 2.3 \\
0.2 \pm 0.1 \\
11.2 \pm 3.7 \mathrm{ab}\end{array}$ & $\begin{array}{c}0.5 \pm 0.1 \mathrm{ab} \\
8.5 \pm 1.6 \mathrm{ab} \\
5.6 \pm 3.4 \\
0.6 \pm 0.1 \\
12.2 \pm 2.0 \mathrm{ab}\end{array}$ & $\begin{array}{c}3.2 \pm 0.7 \mathrm{a} \\
15.1 \pm 1.3 \mathrm{a} \\
3.0 \pm 2.1 \\
0.2 \pm 0.1 \\
25.7 \pm 1.5 \mathrm{a}\end{array}$ \\
\hline
\end{tabular}

-Values within a row followed by the same letter are not significantly different at the 0.10 probability level. 
subjected to a two-way (brush treatment $\times$ grazing level) ANOVA to test the hypothesis that there were no differences in density of herbs because of brush treatment or goat-stocking levels at any specific time.

Homogeneity of variances were tested in all cases using Cochran's C. In those cases where mean separation tests were indicated, they were done via Tukey's (HSD). All analyses were accomplished using SPSS/PC+ (Norusis 1988a, 1988b). Those mean separation tests done at $P=0.10$ also used Tukey but via a program developed by R. King (Rocky Mountain Forest and Range Experiment Station, Fort Collins, Colo.) using Scheffe's (1959) tables.

\section{Soils and Litter}

Homogeneity of variance was tested using the Cochran and Bartlett-Box test for soils and litter, respectively. Soil and litter data were analyzed with a two-way ANOVA that treated stocking level and brush crushing as main effects. Statistical differences between means for different stocking levels were determined at the 0.05 level using a Tukey (HSD) test.

\section{Results and Discussion}

\section{Vegetation Response}

\section{Shrubs}

Percentage cover of total shrubs and of shrub live oak was not different $(P>0.05)$ among the 16 study paddocks prior to applying treatments; however, paddocks differed $(P<0.05)$ in amounts of most and least preferred shrubs (Table 1).

Total Shrubs. No interactions $(P>0.05)$ were found involving stocking level, brush treatment, or time for total shrub cover from May 1985 through May 1988. Mean total shrub cover was lower $(P<0.05)$ on paddocks where shrubs were crushed vs not crushed (33 \pm 1 and $50 \pm 3 \%$, respectively) across stocking levels and times. Paddocks not browsed had higher $(P<0.05)$ total shrub cover percentages than did paddocks that were stocked at light, moderate, or heavy rates $(51 \pm 2,38 \pm 1,39 \pm 1 \%$, and $35 \pm 1 \%$, respectively). However, light, moderate, or heavy stocking levels were similar $(P>0.05)$.

Orthogonal polynomial contrasts revealed a quadratic effect $(P<0.05)$ over time. While a linear effect due to goat browsing might be expected, the parabolic form realized can be attributed to an initial increase in shrub cover from October 1985 to May 1986 (Table 1; group means were $36 \pm 4$ and $43 \pm 4 \%$, respectively). Increases were likely due to a warm, wet 1986 winter, excellent growing conditions for chaparral vegetation. Weather records from Roosevelt, Ariz., indicate January, March, and April 1986 had mean monthly temperatures $2.7,2.5$, and $1.4^{\circ} \mathrm{C}$ above normal, respectively (February temperature data were missing). February and March precipitation was of 46.2 and $30.0 \mathrm{~mm}$ above normal, respectively. Shrub growth during this period and into the following summer apparently negated browsing effects by goats. This trend continued through October 1986 (group mean $45 \pm 4 \%$ ). Thereafter, total shrub cover decreased to $41 \pm 4 \%$ by May 1988 . These data indicate chaparral growth can be controlled by goats, but effects may be nullified if optimum growing conditions for shrubs are present and stocking levels are not adjusted accordingly.

Crushing brush immediately prior to goat browsing will help maintain reductions in shrub cover. Total cover of crushed shrubs in unbrowsed paddocks was similar $(P>0.05)$ to unbrowsed, uncrushed treatments by the last sampling period (Table 1). Heavily and moderately stocked paddocks had less $(P<0.05)$ shrub cover than did the browsed, uncrushed paddocks $(P<0.10)$. The lightly stocked, crushed areas were similar $(P>0.05)$ to the heavily stocked, uncrushed paddocks but different $(P<0.05)$ from the other uncrushed, moderately and heavily browsed areas. These results confirm one recommendation of Davis et al. (1975) that goats can be effective in suppressing brush, provided that the stand was first treated mechanically, chemically, or by fire.

Shrub Live Oak. There was no stocking level $\times$ brush treatment interaction $(P>0.05)$ for shrub live oak cover. Group means for brush treatments differed ( $P<0.05), 19 \pm 1$ and $26 \pm 1 \%$ for crushed and not crushed paddocks, respectively. Goat-stocking levels influenced shrub live oak cover. Ungrazed paddocks contained higher $(P<0.05)$ percentages $(31 \pm 1 \%)$ of live oak than did light, moderate, and heavy browsed plots $22 \pm 1,20 \pm 1$, and $17 \pm$ $1 \%$, respectively). Lightly stocked paddocks contained more oak $(P<0.05)$ than did the heavily browsed ones.

Stocking level $\times$ time and brush treatment $\times$ time interactions

Table 3. The effect of different goat stocking levels on select litter properties under manzanita, shrub live oak, and ceanothus plants and on bare areas. Data expressed as mean \pm standard error.

\begin{tabular}{|c|c|c|c|c|}
\hline \multirow[b]{2}{*}{ Litter property } & \multirow[b]{2}{*}{ Cover } & \multicolumn{3}{|c|}{ Stocking levels } \\
\hline & & None & Light & Heavy \\
\hline Total litter $\left(\mathrm{g} / \mathrm{m}^{2}\right)$ & $\begin{array}{l}\text { Manzanitta } \\
\text { Ceanothus } \\
\text { Shrub live oak } \\
\text { Bare areas }\end{array}$ & $\begin{array}{c}3166 \pm 59 \mathrm{a} \\
1309 \pm 69 \mathrm{a} \\
1299 \pm 187 \mathrm{a} \\
280 \pm 44 a\end{array}$ & $\begin{array}{l}976 \pm 12 \mathrm{ab} \\
360 \pm 88 \mathrm{~b} \\
859 \pm 117 \mathrm{ab} \\
136 \pm 35 \mathrm{a}\end{array}$ & $\begin{array}{c}1738 \pm 48 b \\
437 \pm 117 b \\
764 \pm 92 b \\
138 \pm 15 a\end{array}$ \\
\hline Total nitrogen $\left(\mathrm{g} / \mathrm{m}^{2}\right)$ & $\begin{array}{l}\text { Manzanita } \\
\text { Ceanothus } \\
\text { Shrub live oak } \\
\text { Bare areas }\end{array}$ & $\begin{array}{c}154 \pm 24 a \\
138 \pm 5 a \\
138 \pm 24 a \\
19 \pm 6 a\end{array}$ & $\begin{array}{c}64 \pm 6 b \\
32 \pm 10 b \\
106 \pm 20 a b \\
13 \pm 4 a\end{array}$ & $\begin{array}{l}79 \pm 26 b \\
75 \pm 8 b \\
67 \pm 11 b \\
14 \pm 5 a\end{array}$ \\
\hline Percent nitrogen (\%) & $\begin{array}{l}\text { Manzanita } \\
\text { Ceanothus } \\
\text { Shrub live oak } \\
\text { Bare areas }\end{array}$ & $\begin{array}{l}0.51 \pm .03 \mathrm{ab} \\
1.07 \pm .08 \mathrm{a} \\
1.05 \pm .07 \mathrm{ab} \\
0.76 \pm .15 \mathrm{a}\end{array}$ & $\begin{array}{l}0.67 \pm 0.7 \mathrm{a} \\
0.85 \pm .11 \mathrm{a} \\
1.21 \pm .08 \mathrm{a} \\
0.86 \pm .23 \mathrm{a}\end{array}$ & $\begin{array}{l}0.43 \pm .06 b \\
0.78 \pm .08 \mathrm{a} \\
0.86 \pm .06 \mathrm{~b} \\
0.95 \pm .20 \mathrm{a}\end{array}$ \\
\hline Total phosphorus $\left(\mathrm{g} / \mathrm{m}^{2}\right)$ & $\begin{array}{l}\text { Manzanita } \\
\text { Ceanothus } \\
\text { Shrub live oak } \\
\text { Bare areas }\end{array}$ & $\begin{array}{c}32 \pm 8 \mathrm{a} \\
14 \pm 1 \mathrm{a} \\
17 \pm 2 \\
3 \pm 1 \mathrm{a}\end{array}$ & $\begin{array}{c}25 \pm 10 \mathrm{a} \\
4 \pm 1 \mathrm{~b} \\
13 \pm 2 \mathrm{a} \\
2 \pm 1\end{array}$ & $\begin{array}{r}12 \pm 2 \mathrm{a} \\
3 \pm 1 \mathrm{~b} \\
6 \pm 1 \mathrm{~b} \\
2 \pm 1 \mathrm{a}\end{array}$ \\
\hline Percent phosphorus (\%) & $\begin{array}{l}\text { Manzanita } \\
\text { Ceanothus } \\
\text { Shrub live oak } \\
\text { Bare areas }\end{array}$ & $\begin{array}{l}0.10 \pm .01 \mathrm{a} \\
0.10 \pm .01 \mathrm{a} \\
0.14 \pm .01 \mathrm{a} \\
0.09 \pm .02 \mathrm{a}\end{array}$ & $\begin{array}{l}0.31 \pm .16 a \\
0.11 \pm .01 a \\
0.15 \pm .01 a \\
0.14 \pm .05 a\end{array}$ & $\begin{array}{l}0.08 \pm .01 \mathrm{a} \\
0.08 \pm .01 \mathrm{~b} \\
0.08 \pm .01 \mathrm{~b} \\
0.12 \pm .02 \mathrm{a}\end{array}$ \\
\hline
\end{tabular}

*Any numbers in a row having the same letters $(a, b)$ are not significantly different at the 0.05 level. 
were significant $(P<0.05)$, precluding determination of an overall time trend.

Benefits afforded by crushing were not as evident with shrub live oak as with total shrubs, but the recommendations of Davis et al. $(1975)$ are still valid. While there were no differences $(P>0.05)$ in shrub live oak cover prior to any treatment, by the last sampling date the moderately and heavily stocked, crushed paddocks contained less $(P<0.10)$ oak cover than any of the uncrushed paddocks except the heavily stocked ones (Table 1).

Most Preferred Shrubs. The most preferred shrubs were impacted by all stocking levels. Analysis of covariance to adjust for heterogeneous pretreatment conditions failed because the regression was nonsignificant $(P>0.05)$. Therefore, a simple correction for pretreatment heterogeneity was obtained by computing the relative change after treatment as November 1983 percent cover subtracted from May 1988 percent cover, then divided by November 1983 cover. Analysis of this index indicated effects $(P<0.05)$ associated with both browsing and crushing treatments but no interaction $(P>0.05)$ between them. Cover of the most preferred species was reduced $79 \%$ on the crushed plots versus $54 \%$ on the plots not crushed. The relative changes associated with stocking were decreases of $17,71,89$, and $90 \%$ for $0,1.4,2.4$, and 4.2 goats/ha, respectively. Browsed plot cover was decreased $(P<0.05)$ compared to unbrowsed plots. Preferred shrub cover decreased $(P<0.05)$ consistently where the brush was not crushed. On crushed plots the preferred species never recovered beyond immediate post-crushing levels (Table 1). Mortality of the preferred shrubs in moderate and heavily stocked paddocks ranged from $16.7 \%$ for Wright silktassel to $70.0 \%$ for desert ceanothus as compared to $23.1 \%$ for shrub live oak by October 1987.

The most preferred species started to recover on crushed plots in unbrowsed paddocks, but the increase in cover of these species culminated during fall 1985, to spring 1986, and thereafter decreased (Table 1). Two reasons for this response are offered: (1) Mortality may have been caused by crushing. The increase noted up to October 1985 may have been due to growth of the survivors. (2) These species are also those most preferred by mule and whitetailed deer (Odocoileus hemionus Rafinesque and $O$. virginianus Zimmermann) in this region. Utilization indices on shrubs in paddocks not browsed by goats ranged from 1.00 (Wright silktassel) to 1.35 (hollyleaf buckthorn) as compared to 0.17 for shrub live oak and 0.00 for the least preferred species. Shrub utilization was much less on the unbrowsed, not crushed plots. Presumably this use was by deer and it may have been great enough to impair recovery on the crushed plots.

The most preferred species contributed a high proportion of the decline noted for total shrubs. This is a cause for concern because these species are among those most important to deer in chaparral habitats in Arizona (McCulloch and Urness 1973). Knipe (1983) also noted a decrease in these shrubs and expressed similar concerns.

The decline in cover of preferred shrub species such as desert ceanothus may influence long-term nitrogen cycling in chaparral ecosystems. Desert ceanothus has been reported as an important nitrogen-fixing shrub in California chaparral (Kummerow et al. 1978). If such species are eliminated by continued overutilization, long-term nitrogen cycling could be adversely affected.

Least Preferred Shrubs. There were essentially no changes in percentage cover in the uncrushed paddocks while those in the crushed paddocks increased gradually from November 1983 to May 1988 (Table 1). By May 1988, there were no differences $(P>0.05)$ noted in cover of the shrubs least preferred by goats among stocking levels or between brush treatments.

\section{Herbs}

Although there were some differences $(P<0.10)$ in density of perennial grasses among treatments during the two 1986 measurement periods, they were not consistent and did not appear related to treatments (Table 2). No differences $(P>0.10)$ were noted over the last 3 measurement periods. There were no general trends indicating a change in density over time for perennial grasses. May 1988 densities were similar to those noted in May 1986. Perennial forb density appeared higher during May 1987 and May 1988 as compared to May 1986. However, these increases are consistent across all treatments.

Annuals responded to treatments, but the responses appear related to soil surface disturbance, in general, rather than to stocking levels or brush treatments per se. Annual grasses had higher densities $(P<0.10)$ in paddocks that were crushed, regardless of stocking level, and paddocks that were not crushed but received the heaviest stocking rates (Table 2). Annual grasses, primarily red brome, were not homogeneous within paddocks but were concentrated under shrubs or, in crushed paddocks, in shrub litter rather than between shrubs. Soil surface disturbance, whether caused by the Marden crusher or by goat hoof action, combined with higher organic matter contents of the soil in areas previously occupied by shrubs, resulted in high annual grass densities. Less total litter $(P<0.05)$ occurred in bare areas compared to under shrubs (Table 3 ), which was further reflected in lower organic carbon content of soil in the bare areas (Table 4). The additional organic matter would provide more favorable moisture and fertility conditions. Annual forb densities were higher in paddocks that were crushed and received the highest stocking rates during the first 2 measurement periods, while trends during May 1988 generally followed annual grasses (Table 2).

\section{Litter and Soil Responses \\ Goat Browsing}

Litter. Less $(<0.05)$ litter accumulated under manzanita, desert ceanothus, and shrub live oak plants on heavily stocked paddocks compared to beneath those plants in unbrowsed paddocks (Table 3). Litter was reduced $(P<0.05)$ under light stocking rates only under ceanothus. Browsing had no effect $(P>0.05)$ on the amount of litter found in bare areas, although less was found on the interspaces of heavily stocked paddocks.

Heavy goat-stocking levels decreased $(P<0.05)$ total $\mathrm{N}\left(\mathrm{g} / \mathrm{m}^{2}\right)$ in the litter under manzanita, desert ceanothus, and shrub live oak (Table 3). Stocking levels did not affect $(P>0.05)$ total litter $N$ on bare areas. Lower $(P<0.05)$ concentrations of total percent $N$ were found in the litter of plants on heavily stocked paddocks compared to the lightly stocked paddocks under manzanita and shrub live oak (Table 3). There were no differences $(P>0.05)$ between browsing versus no browsing.

Total $P\left(\mathrm{~g} / \mathrm{cm}^{2}\right)$ in desert ceanothus litter was higher $(P<0.05)$ in the unbrowsed paddocks compared to either light or heavy stocked paddocks (Table 3). Under shrub live oak, total $P$ in the litter was less $(P<0.05)$ under heavy stocking compared to light and no goat use. As with $\mathbf{N}$, total percent $\mathbf{P}$ of ceanothus plants was lower $(P<0.05)$ in the litter under heavy compared to light stocking rates. Under shrub live oak, percent total $P$ in the litter was less $(P<0.05)$ under heavy stocking compared to light and no goat browsing (Table 3). Browsing had no effect $(P>0.05)$ on the $P$ content of litter under manzanita or in bare areas.

The effect of browsing on both litter and nutrients accumulating under shrubs probably reflected the consumption, by goats, of leaves and twigs that were either retained on the standing plants or that had dropped to the ground and accumulated under the shrub canopies. Although species such as manzanita and shrub live oak are considered less palatable and were not heavily utilized, it 
Table 4. The effect of different goat stocking levels on select soil properties in the 0 - to $3.8 \mathrm{~cm}$ depth under manzanita, shrub live oak, and ceanothus plants and on bare areas. Data expressed as mean \pm standard error.

\begin{tabular}{|c|c|c|c|c|}
\hline \multirow[b]{2}{*}{ Soil property } & \multirow[b]{2}{*}{ Cover } & \multicolumn{3}{|c|}{ Stocking levels } \\
\hline & & None & Light & Heavy \\
\hline Bulk density $\left(\mathrm{g} / \mathrm{m}^{3}\right)$ & $\begin{array}{l}\text { Manzanita } \\
\text { Ceanothus } \\
\text { Shrub live oak } \\
\text { Bare areas }\end{array}$ & $\begin{array}{l}1.27 \pm .06 \mathrm{a}^{*} \\
1.23 \pm .05 \mathrm{~b} \\
1.25 \pm .09 \mathrm{a} \\
1.62 \pm .06 \mathrm{a}\end{array}$ & $\begin{array}{l}1.37 \pm .08 \mathrm{a} \\
1.50 \pm .04 \mathrm{a} \\
1.29 \pm .05 \mathrm{a} \\
1.71 \pm .08 \mathrm{a}\end{array}$ & $\begin{array}{l}1.22 \pm .11 \mathrm{a} \\
1.49 \pm .07 \mathrm{a} \\
1.29 \pm .06 \mathrm{a} \\
1.69 \pm .07 \mathrm{a}\end{array}$ \\
\hline Organic carbon (\%) & $\begin{array}{l}\text { Manzanita } \\
\text { Ceanothus } \\
\text { Shrub live oak } \\
\text { Bare areas }\end{array}$ & $\begin{array}{l}3.07 \pm .60 \mathrm{a} \\
2.92 \pm .72 \mathrm{a} \\
2.20 \pm .43 \mathrm{a} \\
0.48 \pm .25 \mathrm{a}\end{array}$ & $\begin{array}{l}0.85 \pm .09 \mathrm{a} \\
0.78 \pm .11 \mathrm{~b} \\
2.18 \pm .70 \mathrm{a} \\
0.44 \pm .19 \mathrm{a}\end{array}$ & $\begin{array}{l}6.67 \pm 2.9 \mathrm{a} \\
0.95 \pm .14 \mathrm{~b} \\
2.35 \pm .80 \mathrm{a} \\
0.60 \pm .26 \mathrm{a}\end{array}$ \\
\hline Total nitrogen (\%) & $\begin{array}{l}\text { Manzanita } \\
\text { Ceanothus } \\
\text { Shrub live oak } \\
\text { Bare areas }\end{array}$ & $\begin{array}{l}0.09 \pm .10 \mathrm{a} \\
0.11 \pm .03 \mathrm{a} \\
0.13 \pm .03 \mathrm{a} \\
0.06 \pm .02 \mathrm{a}\end{array}$ & $\begin{array}{l}0.04 \pm .03 \mathrm{a} \\
0.05 \pm .01 \mathrm{a} \\
0.13 \pm .04 \mathrm{a} \\
0.05 \pm .02 \mathrm{a}\end{array}$ & $\begin{array}{l}0.14 \pm .10 \mathrm{a} \\
0.07 \pm .01 \mathrm{a} \\
0.17 \pm .04 \mathrm{a} \\
0.04 \pm .02 \mathrm{a}\end{array}$ \\
\hline Total phosphorus (\%) & $\begin{array}{l}\text { Manzanita } \\
\text { Ceanothus } \\
\text { Shrub live oak } \\
\text { Bare areas }\end{array}$ & $\begin{array}{l}0.100 \pm .010 \mathrm{a} \\
0.103 \pm .008 \mathrm{a} \\
0.118 \pm .003 \mathrm{a} \\
0.125 \pm .007 \mathrm{a}\end{array}$ & $\begin{array}{l}0.110 \pm .013 \mathrm{a} \\
0.125 \pm .007 \mathrm{a} \\
0.133 \pm .007 \mathrm{a} \\
0.127 \pm .010 \mathrm{a}\end{array}$ & $\begin{array}{l}0.089 \pm .016 a \\
0.113 \pm .013 a \\
0.096 \pm .008 b \\
0.085 \pm .013 b\end{array}$ \\
\hline
\end{tabular}

*Any numbers in a row having the same letters $(a, b)$ are not significantly different at the 0.05 level.

appears significant amounts of plant leaf and twig material were removed by the goats and, as a result, less litter accumulated on the soil surface. A reduction in litter quality, as indicated by lower percent total $\mathbf{N}$ in the litter, suggests that goats are selective for those plant parts containing the highest concentrations of $\mathbf{N}$ (e.g., proteins), such as leaves and smaller stems. Decreased litter quality, as indicated by lower concentrations of $\mathbf{N}$ and $P$, was most apparent when comparing heavily stocked to lightly stocked and unbrowsed paddocks.

The effect of goat browsing on litter and nutrient accumulation beneath shrubs has implications on the long-term fertility and productivity of chaparral ecosystems. Chaparral shrubs are typically found on nutrient-poor soils (Hellmers et al. 1955a). One mechanism by which chaparral shrubs have adapted to nutrientpoor soil is believed to be through the accumulation and recycling of nutrients in litter, humus, and soil under shrub canopies. Because chaparral shrubs have extensive root systems they can exploit large volumes of soil for water and nutrients (Hellmers et al. 1955b, Davis and Pase 1977). Nutrients absorbed by shrubs are immobilized in organic matter for several years before they are slowly released into the soil (Schlesinger 1985, Schlesinger and Hasey 1981), suggesting that soil fertility and nutrient availability for plant growth can be enhanced by the accumulation and slow release of plant nutrients through decomposition and mineralization of plant litter. Therefore, any interruption of litter accumulation and decomposition could have important consequences on the long-term stability of chaparral ecosystems. Goats appear to effectively interrupt the accumulation of litter, particularly under preferred shrubs. Presumably this loss of litter and nutrients under shrub canopies reflects a redistribution of the ingested material to either interspaces between shrubs, or in bedding areas. However, there were no detectable differences in interspace litter and nutrients between the different intensities of browsing, suggesting that the litter and associated nutrients that were lost from under shrub canopies were probably concentrated as fecal material in bedding areas.

Soil. Stocking level had no effect $(P>0.05)$ on bulk density in the upper soil depth except under desert ceanothus plants where soil bulk density under the light and heavy stocking levels was higher $(P<0.05)$ than in unbrowsed paddocks (Table 4). Bulk density was not measured in the $3.8-$ to $10-\mathrm{cm}$ soil depth. Vegetation utilization and mortality measurements showed that desert ceanothus underwent the highest intensity of browsing (utilization indices ranged from 2.71 to 3.00 ), which could have increased $(P>0.05)$ the bulk density under this species compared to manzanita (indices from 0.71 to 1.59 ) and shrub live oak (indices from 1.69 to 2.68).

In soil under ceanothus cover, organic carbon $(O C)$ concentrations were higher $(P<0.05)$ under no browsing compared to light and heavy stocking levels. Stocking levels had no impact $(P>0.05)$ on OC under shrub live oak, manzanita, and in bare areas (Table 4). There were no effects $(P>0.05)$ of stocking level on $O C$ in the 3.8- to 10-cm soil depth (data not presented).

No differences $(P>0.05)$ were found in percent $N$ in the surface soil layer under any of the shrub species studied because of browsing (Table 4). Browsing had no effect $(P>0.05)$ on the total percent $\mathbf{P}$ under Pringle manzanita, desert ceanothus, and in bare areas. However, lower $(P<0.05)$ percent total $P$ was present in the soil under shrub live oak that had been browsed heavily compared to light stocking and no goat use (Table 4). Soil $N$ and $P$ at the 3.8- to $10-\mathrm{cm}$ depth were not affected $(P>0.05)$ by stocking levels.

The chemical and physical properties of soil were generally less sensitive to goat browsing than was the litter component, and changes were restricted to the upper soil layer (0- to 3.8-cm depth), with no changes ( $P>0.05$ ) occurring in the 3.8- to $10-\mathrm{cm}$ layer. Soil changes in response to grazing disturbance in open shrubland ranges in Australia have been reported to be limited to less than 10 $\mathrm{cm}$ from the soil surface (Graetz and Tongway 1986). The decreases in $\mathbf{N}, \mathbf{P}$, and $\mathrm{OC}$ in response to goat browsing were expected because similar changes have been reported in response to high grazing pressure by sheep on grasslands in Australia (Simpson et al. 1974) and India (Pandey and Sant 1979).

\section{Brush Crushing}

Crushing increased $(P<0.05)$ the amount of litter, total litter $N$, and total $P$ under shrub live oak but had no effect $(P>0.05)$ under manzanita, desert ceanothus, or on bare areas. Concentrations of $\mathrm{N}$ and $\mathrm{P}$ in the litter were not affected $(P>0.05)$ by brush crushing.

Not many of the soil properties were affected by crushing. Although there was increased soil bulk density under all cover types associated with crushing, the differences were higher $(P<0.05)$ only under manzanita, and nonsignificant $(P>0.05)$ on bare interspace areas.

\section{Conclusions and Management Implications}

The higher levels of goat stocking tested in this study reduced 
total shrub cover in Arizona chaparral stands, particularly when done in conjunction with an initial brush crushing treatment. Goat-stocking rates also affected litter accumulation and the underlying soil. These results point out several ramifications that need to be considered when designing a goat-browsing system in Arizona chaparral.

First, perennial herbaceous vegetation did not increase in response to decreasing shrub cover, at least over the 4-1/2 year period of this study and under the condition described. If this trend continues, there will be less plant cover to protect the soil and a greater potential for increased erosion. Although annuals responded to disturbance, their ephemeral nature and distribution pattern (under shrubs and not in interspaces) make them generally ineffective as soil protectors. Because of this, we concur with Knipe (1983) - it may be necessary to reseed perennial grasses in order to obtain an adequate herbaceous cover.

Second, a decline in forage diversity would set the stage for nutritional stress. Those shrubs most affected by goats were those also preferred by native deer. Chaparral habitats are, under normal conditions, nutritionally marginal for deer (McCulloch and Urness 1973). Deer, like goats, are selective feeders and tend to overcome nutritional limitations of forage by selecting the most nutritious parts, within and among plant species. Reducing forage diversity by eliminating the most desired species from the forage base would likely impact these native ungulates. The importance of a diverse forage base for providing nutritionally adequate diets has been noted by Dietz et al. (1962). This was not a problem in Utah where goats were used to control Gambel oak. There, shrubs used (and reduced) by goats were generally those not preferred by wintering mule deer (Riggs and Urness 1989).

Third, goat browsing also affected the litter and underlying soil greatest under a preferred shrub, desert ceanothus. The trampling associated with any level of goat browsing on desert ceanothus was also sufficient to produce changes in some physical and chemical properties of the underlying soil. As a result, it is possible that goat browsing of ceanothus could adversely affect nitrogen cycling not only by interfering with litter accumulation and decomposition but, more importantly, by eliminating this important nitrogenfixing shrub from the chaparral stand. Ceanothus species have been estimated to comprise about $11.5 \%$ of the plant cover in Arizona chaparral stands (Carmichael et al. 1978).

Therefore, it appears the selective browsing of important shrubs, and the associated impacts on the soil, will continually be a problem when designing goat-browsing strategies in Arizona chaparral. Possible solutions may involve more refined management methods designed to reduce selectivity by goats (Savory 1988) or by including perennial forb mixtures in reseeding programs. Either method, using present technology, would be complex. The key, however, may lie in keeping goat operations confined to relatively small proportions of the total landscape.

Our results substantiate Knipe's (1983) conclusions that the successful use of goats to control shrubs in Arizona chaparral will require very intensive levels of management. In the final analysis, it appears that any goat browsing management strategy must be sufficiently comprehensive to protect both the vegetation and soil resource.

\section{Literature Cited}

Black, M.L. 1958. Soil chemical analysis. Prentice-Hall Inc., Englewood Cliffs, N.J.

Boles, Patrick H. 1987. Vegetation changes in chaparral within an Angora goat/short duration grazing cell in north-central Arizona. p. 27-46. In: Challenges and opportunities in chaparral management. Proc. Southwest. Soc. Amer. Forest Annua. Meet., November 12-14, 1986, Prescott, Ariz., Northern Arizona Univ., School of Forestry, Flagstaff.
Canfield, R.H. 1942. Application of the line interception method of sampling range vegetation. J. Forest. 39:388-394.

Carmichael, R.S., O.D. Knipe, C.P. Pase, and W.W. Brady. 1978. Arizona chaparral: Plant association and ecology. USDA Forest. Serv. Res. Pap. RM-202, Rocky Mt. Forest Range Exp. Sta., Fort Collins, Colo.

Davis, E.A., and C.P. Pase. 1977. Root system of shrub live oak: Implications for water yield in Arizona chaparral. J. Soil Water Conserv. 32:174-180.

Davis, G.G., L.E. Bartel, and C.W. Cook. 1975. Control of Gambel oak sprouts by goats. J. Range Manage. 28:216-218.

Dietz, D.R., R.H. Udall, and L.E. Yeager. 1962. Chemical composition and digestibility by mule deer of selected forage species, Cache La Poudre Range, Colorado. Colorado Game Fish Dep. Tech. Pub. 14.

Graetz, R.D., and D.J. Tonway. 1986. Influence of grazing management on vegetation, soil structure and nutrient distribution and the infiltration of applied rainfall in a semi-arid chenopod shrubland. Australian J. Ecol. 11:347-360.

Gray, J.T., and W.H. Schlesinger. 1981. Nutrient cycling in Mediterranean type ecosystems. P. 259-285. In: P.C. Miller (ed.), Resource use by chaparral and matorral. Ecological Studies 39. Springer-Verlag, New York.

Green, Lisle R., Catherine L. Hughes, and Walter L. Graves. 1978. Goat control of brush regrowth on southern California fuelbreaks. P.451-455. In: Proc. First Internat. Range Congr. Soc. Range Manage., August 14-18, 1978, Denver, Colo.

Hellmers, H., J.F. Bonner, and J.M. Kelleher. 1955a. Soil fertility: A watershed management problem in the San Gabriel mountains of southern California. Soil Sci. 80:189-197.

Hellmers, H., J.S. Horton, G. Juhren, and J. O'Keefe. 1955b. Root systems of some chaparral plants in southern California. Ecology 36:667-678.

Hibbert, A.R., E.A. Davis, and D.G. Scholl. 1974. Chaparral conversion potential in Arizona: Part I: Water yield response and effects on other resources. USDA Forest Serv. Res. Pap. RM-126, Rocky Mt. Forest Range Exp. Sta., Fort Collins, Colo.

Klute, A. (ed.). 1986. Methods of soil analysis. Part 1. Physical and mineralogical methods. Agron. Ser. No. 9. Amer. Soc. Agron., Madison, Wis.

Knipe, O.D. 1983. Effects of angora goat browsing on burned-over Arizona chaparral. Rangelands 5:252-255.

Kummerow, J., J.V. Alexander, J.W. Neel, and K. Fishbeck. 1978. Symbiotic nitrogen fixation in Ceanothus roots. Amer. J. Bot. 65:63-69.

McCulloch, C.Y., and P.J. Urness. 1973. Deer nutrition in Arizona chaparral and desert habitats. Arizona Game and Fish Dep. Spec. Rep. 3.

Norusis, M.J. 1988a. SPSS/ PC+ V2.0 Base Manual, SPSS, Inc., 444 N. Michigan Ave., Chicago, Ill.

Norusis, M.J. 1988b. SPSS/ PC+ Advanced Statistics V2.0, SPSS Inc. 444 N. Michigan Ave., Chicago, Ill.

Page, A.L., R.H. Miller, and D.R. Keeney (ed.). 1982. Methods of soil analysis. Part 2. Chemical and microbial properties, 2nd edition. Agron. Ser. 9. Amer. Soc. Agron., Madison, Wis.

Pandey, D.D., and H.R. Sant. 1979. The effect of grazing on chemical properties of grassland soils at Varanasi. Indian J. Ecol. 6:7-11.

Riggs, Robert A., and Phillip J. Unness. 1989. Effects of goat browsing on Gambel oak communities in northern Utah. J. Range Manage. 42:354-360.

Savory, A. 1988. Holistic resource management. Island Press, Covelo, Calif.

Scheffe, H. 1959. The analysis of variance. John Wiley and Sons, New York.

Schlesinger, W.H. 1985. Decomposition of chaparral shrub foliage. Ecology 66:1353-1359.

Schlesinger, W.H., and M.M. Hasey. 1981. Decomposition of chaparral shrub foliage: Losses of organic and inorganic constituents from deciduous and evergreen leaves. Ecology 62:762-774.

Simpson, J.R., S.M. Bromfield, and O.L. Jones. 1974. Effects of management on soil fertility under pasture. 3. Changes in total soil nitrogen, carbon, phosphorus and exchangeable cations. Australian J. Exp. Agr. Anim. Husb. 14:487-494.

Vallentine, J.F. 1980. Range development and improvements. 2nd ed. Brigham Young University Press, Provo, Utah. 